\title{
The Effect of Carbon Coating on the Electrochemical Performance of Nanosized $\mathrm{Li}_{2} \mathrm{FeSiO}_{4}$ Cathode Materials
}

\author{
Y. WANG*, D. Su AND G. WANG \\ Research Centre for Clean Energy Technology, School of Chemistry and Forensic Science, University of Technology \\ Sydney, City Campus, Broadway, Sydney, NSW 2007, Australia
}

\begin{abstract}
Carbon-coated $\mathrm{Li}_{2} \mathrm{FeSiO}_{4} / \mathrm{C}$ cathode materials have been synthesized through a modified ball-milling process. The physical characterizations of $\mathrm{Li}_{2} \mathrm{FeSiO}_{4}$ were conducted by using X-ray powder diffraction, field-emission scanning electron microscopy and transmission electron microscopy techniques. Field-emission scanning electron microscopy and transmission electron microscopy images revealed that $\mathrm{Li}_{2} \mathrm{FeSiO}_{4} / \mathrm{C}$ consists of nanosized particles coated with an amorphous carbon layer. The electrochemical performances of $\mathrm{Li}_{2} \mathrm{FeSiO}_{4} / \mathrm{C}$ cathode materials were evaluated through fully assembled lithium batteries via cyclic voltammetry, charge/discharge test and electrochemical impedance spectroscopy. The $\mathrm{Li}_{2} \mathrm{FeSiO}_{4} / \mathrm{C}$ cathode materials showed a much improved electrochemical performance in terms of higher specific capacity, better cycling performance and less charge transfer resistance than that of the pristine $\mathrm{Li}_{2} \mathrm{FeSiO}_{4}$.
\end{abstract}

DOI: 10.12693/APhysPolA.123.279

PACS: 61.05.cp, 61.46.Hk, 68.37.-d

\section{Introduction}

With global demand for renewable energy, rechargeable lithium ion batteries have become the most promising energy storage devices. However, the application of conventional lithium ion batteries using transition-metal oxides as the cathode materials has been limited because of their high cost, toxicity, scarcity, and safety concerns [1]. Since Goodenough's group first reported lithium iron phosphate $\left(\mathrm{LiFePO}_{4}\right)$ in 1997 [2], many efforts have been devoted to develop the polyanion-type cathode materials such as phospho-olivines and lithium metal orthosilicates, due to their enhanced stability and safety compared with transition metal oxides $[3,4]$. Among them, $\mathrm{LiFePO}_{4}$ has been emerging as the most important cathode material for large-scale applications $[5,6]$. In particular, the poor electronic conductivity of $\mathrm{LiFePO}_{4}$ can be dramatically improved through carbon coating technique $[7,8]$.

In an effort to search cheaper cathode material with satisfying electrochemical properties, $\mathrm{Li}-\mathrm{M}-\mathrm{Si}-\mathrm{O}(\mathrm{M}=$ $\mathrm{Fe}, \mathrm{Mn}, \mathrm{Co}$ ) system has been proposed as new materials for lithium ion batteries and has attracted great interests, because it can theoretically deliver two lithium per formula based on the $\mathrm{M}^{4+} / \mathrm{M}^{2+}$ redox reaction to achieve a high theoretical capacity of $330 \mathrm{mAh} / \mathrm{g}$ [9]. Recently, several methods have been proposed to synthesize $\mathrm{Li}_{2} \mathrm{FeSiO}_{4}$, including solid state reaction $[10,11]$, solgel [12, 13], hydrothermal method [14], the Pechini synthesis [15], and microwave-solvothermal synthesis [16]. Nyten et al. first reported $\mathrm{Li}_{2} \mathrm{FeSiO}_{4}$ as the cathode material delivering a reversible capacity of $130 \mathrm{mAh} / \mathrm{g}$ at $60{ }^{\circ} \mathrm{C}$ [17]. Dominko and his co-workers [14] successfully

*corresponding author synthesized $\mathrm{Li}_{2} \mathrm{MnSiO}_{4}$. However, they only delivered $55 \%$ of their theoretical capacity (based on one lithium ion extraction) at room temperature due to the relatively low electronic conductivity, which is 3 orders of magnitude lower than that of $\mathrm{LiFePO}_{4}$. Later, nanostructured $\mathrm{Li}_{2} \mathrm{MSiO}_{4}(\mathrm{M}=\mathrm{Mn}$ and $\mathrm{Fe})$ was prepared and delivered the discharge capacities of $148 \mathrm{mAh} / \mathrm{g}$ at room temperature and $204 \mathrm{mAh} / \mathrm{g}$ at $55^{\circ} \mathrm{C}$ [16]. The performance of $\mathrm{Li}_{2} \mathrm{MSiO}_{4}$ were also improved by embedding small particles in a carbon matrix and by introducing carbon as a conductive agent [15].

Based on our understanding, carbon-coating strategy could be an efficient way to enhance the electronic conductivity of pristine $\mathrm{Li}_{2} \mathrm{FeSiO}_{4}$. In this paper, pristine and carbon-coated $\mathrm{Li}_{2} \mathrm{FeSiO}_{4} / \mathrm{C}$ cathode materials were prepared via a modified ball-milling method. The glycolic acid was used as the carbon source. The structure and electrochemical properties of pristine and $\mathrm{Li}_{2} \mathrm{FeSiO}_{4} / \mathrm{C}$ materials have been systematically investigated.

\section{Experimental}

Stoichiometric amounts of $\mathrm{Li}_{2} \mathrm{CO}_{3} \quad(99.9 \%$ SigmaAldrich), $\mathrm{FeC}_{2} \mathrm{O}_{4} \cdot 2 \mathrm{H}_{2} \mathrm{O}$ (99\% Sigma-Aldrich), and $\mathrm{SiO}_{2}$ (nanopowder, $50 \mathrm{~nm}$ ) were dispersed in a water-ethanol system (50:50 in volume). The mixture was ultrasonically treated for $30 \mathrm{~min}$ and refluxed at $70^{\circ} \mathrm{C}$ for $12 \mathrm{~h}$. After cooling down to room temperature, the mixture was ball-milled with $5 \mathrm{wt} \%$ of glycolic acid in acetone for $16 \mathrm{~h}$. Following the evaporation of acetone, the homogeneous mixtures were sintered at $700^{\circ} \mathrm{C}$ for $10 \mathrm{~h}$ in argon flow. For the preparation of pristine $\mathrm{Li}_{2} \mathrm{FeSiO}_{4}$, all procedures are the same except that no carbon source was added in the ball-milling process.

The phase purity was determined by X-ray powder diffraction (XRPD) using a GBC MMA X-ray diffrac- 
tometer with $\mathrm{Cu} K_{\alpha}$ radiation. The Raman spectroscopy was performed with a Jobin Yvon HR800 confocal Raman system with a laser wavelength of $632.81 \mathrm{~nm}$ on a 300 lines / mm grating at room temperature. Surface morphology and particle size distribution were analyzed by using a field-emission scanning electron microscopy (FESEM, JEOL7500) and transmission electron microscopy (TEM, JEOL JEM 2011). Electrochemical characterizations of the pristine and $\mathrm{Li}_{2} \mathrm{FeSiO}_{4} / \mathrm{C}$ cathode materials were evaluated by assembling CR2032 coin cells in an argon-filled glove box (Mbraun, Unilab, Germany). $\mathrm{Li}_{2} \mathrm{FeSiO}_{4}$ electrode was used as the working electrode, and $\mathrm{Li}$ foil was the counter and reference electrode. The electrolyte was $1 \mathrm{M} \mathrm{LiPF}_{6}$ dissolved in a mixture of ethylene carbonate and dimethyl carbonate $(\mathrm{EC}: \mathrm{DMC}=1: 1)$. The electrodes were made by dispersing $70 \mathrm{wt} \%$ active material, 20 wt $\%$ carbon black, and $10 \mathrm{wt} \%$ polyvinylidene fluoride (PVDF) in $n$-methyl pyrrolidione (NMP) to form a slurry. After that, the slurry was spread onto $\mathrm{Al}$ foil. The coated electrodes were dried at $100{ }^{\circ} \mathrm{C}$ in a vacuum oven overnight. The galvanostatic charge-discharge tests were performed at room temperature on Neware battery tester at different $C$-rates between $1.5-4.8 \mathrm{~V}$. Electrochemical impedance spectroscopy (EIS) was measured on a PARSTAT 2273 Princeton Potentiostat in the frequency range of $10^{5}-10^{-2} \mathrm{~Hz}$.

\section{Results and discussion}

Figure 1 shows the XRPD patterns of the $\mathrm{Li}_{2} \mathrm{FeSiO}_{4}$ and $\mathrm{Li}_{2} \mathrm{FeSiO}_{4} / \mathrm{C}$ materials. Sharp and symmetric diffraction peaks can be detected in both samples, indicating that both samples are well crystallized and can be indexed to orthorhombic phase with the space group of $P m n 2_{1}$. In addition, there is no diffraction peak of carbon in the diffraction line (b). In order to confirm the nature of carbon, the Raman spectrum is presented as the inset in Fig. 1. The $D$-band and $G$-band of carbon reveals that the carbon layer was amorphous.

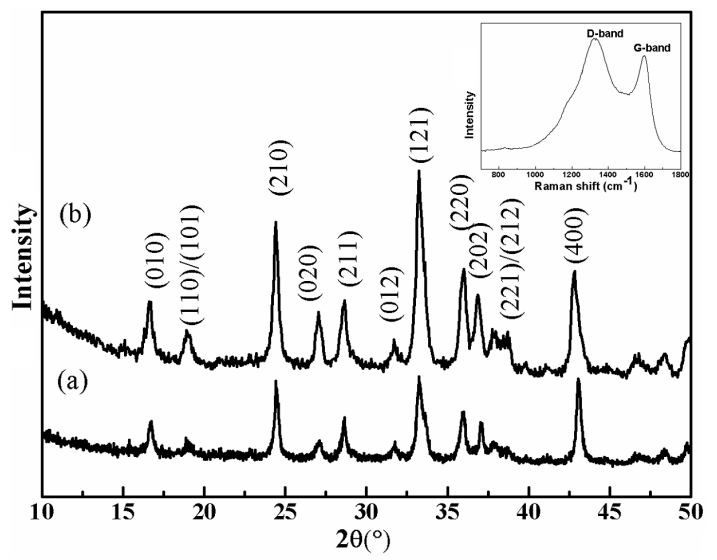

Fig. 1. XRPD patterns of (a) $\mathrm{Li}_{2} \mathrm{FeSiO}_{4}$ and (b) $\mathrm{Li}_{2} \mathrm{FeSiO}_{4} / \mathrm{C}$ and Raman spectrum of $\mathrm{Li}_{2} \mathrm{FeSiO}_{4} / \mathrm{C}$ as an inset.
The morphologies of the $\mathrm{Li}_{2} \mathrm{FeSiO}_{4}$ and $\mathrm{Li}_{2} \mathrm{FeSiO}_{4} / \mathrm{C}$ samples are shown in Fig. $2 \mathrm{a}$ and b, respectively. As shown in Fig. 2a small primary particles of pristine $\mathrm{Li}_{2} \mathrm{FeSiO}_{4}$ tend to form big agglomerates during heat treatment, while $\mathrm{Li}_{2} \mathrm{FeSiO}_{4} / \mathrm{C}$ exhibits better uniformity with the secondary particle size in the range of 200$300 \mathrm{~nm}$.

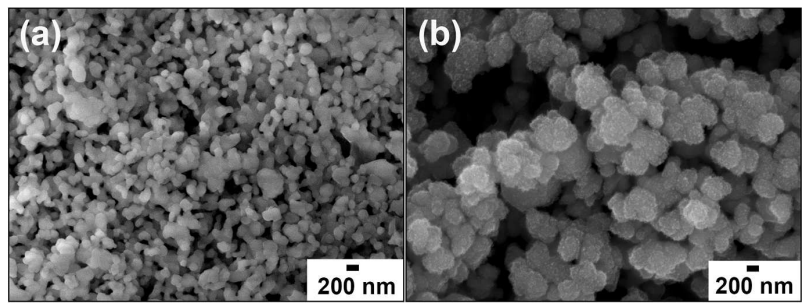

Fig. 2. FESEM images of (a) $\mathrm{Li}_{2} \mathrm{FeSiO}_{4}$ and (b) $\mathrm{Li}_{2} \mathrm{FeSiO}_{4} / \mathrm{C}$.

TEM analysis was conducted to confirm the existence of the carbon layer on the $\mathrm{Li}_{2} \mathrm{FeSiO}_{4} / \mathrm{C}$. Figure $3 \mathrm{a}$ and $\mathrm{b}$ displays TEM images of a typical particle cluster and the enlarged view of the $\mathrm{Li}_{2} \mathrm{FeSiO}_{4} / \mathrm{C}$, respectively. Figure 3 a clearly demonstrates that the $\mathrm{Li}_{2} \mathrm{FeSiO}_{4} / \mathrm{C}$ consists of nanosized particles with good uniformity. An enlarged TEM image in Fig. 3b indicates that the crystal size of $\mathrm{Li}_{2} \mathrm{FeSiO}_{4} / \mathrm{C}$ is in the range of $20-40 \mathrm{~nm}$. The inset in Fig. 3b confirms the presence of carbon layer with the thickness about $1.5-3 \mathrm{~nm}$ (indicated by arrows). During the sintering process, glycolic acid as the carbon source can inhibit particle growth and agglomeration by forming a conductive carbon layer simultaneously on the surface of individual particles.

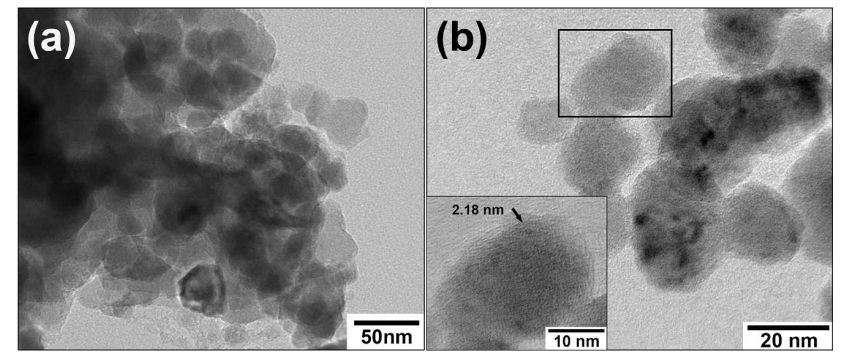

Fig. 3. TEM images of $\mathrm{Li}_{2} \mathrm{FeSiO}_{4} / \mathrm{C}$ at different magnifications (a) and (b). The inset in (b) is the zoom-in nanoparticles shown in the rectangular area.

Figure 4a compares the charge-discharge curves of the $\mathrm{Li}_{2} \mathrm{FeSiO}_{4}$ and $\mathrm{Li}_{2} \mathrm{FeSiO}_{4} / \mathrm{C}$ cathode materials. An obvious shift of the potential plateau from $3.2 \mathrm{~V}$ in the initial charge to $2.9 \mathrm{~V}$ in the second charge can be identified for both samples. This phenomenon is consistent with previous report [18]. The initial discharge capacities of the pristine and $\mathrm{Li}_{2} \mathrm{FeSiO}_{4} / \mathrm{C}$ are $137 \mathrm{mAh} / \mathrm{g}$ and $148 \mathrm{mAh} / \mathrm{g}$, respectively. It should be noted that $\mathrm{Li}_{2} \mathrm{FeSiO}_{4} / \mathrm{C}$ material showed an improved initial Coulombic efficiency $(86 \%)$ than that of pristine 
$\mathrm{Li}_{2} \mathrm{FeSiO}_{4}(77 \%)$. Figure $4 \mathrm{~b}$ shows the cycling performances of the $\mathrm{Li}_{2} \mathrm{FeSiO}_{4}$ and $\mathrm{Li}_{2} \mathrm{FeSiO}_{4} / \mathrm{C}$ cathode materials at various $C$-rates when cycled between $1.5 \mathrm{~V}$ and $4.8 \mathrm{~V}$. Clearly, $\mathrm{Li}_{2} \mathrm{FeSiO}_{4} / \mathrm{C}$ exhibits much better capacity retention and rate capability than that of the $\mathrm{Li}_{2} \mathrm{FeSiO}_{4}$. At $0.1 \mathrm{C}$, the $\mathrm{Li}_{2} \mathrm{FeSiO}_{4}$ and $\mathrm{Li}_{2} \mathrm{FeSiO}_{4} / \mathrm{C}$ cells exhibited the capacity retention of $78.6 \%$ and $90 \%$ over the first 20 cycles, respectively. The $\mathrm{Li}_{2} \mathrm{FeSiO}_{4} / \mathrm{C}$ cathode material is able to deliver a specific capacity of $127 \mathrm{mAh} / \mathrm{g}$ and $111 \mathrm{mAh} / \mathrm{g}$ at $0.2 \mathrm{C}$ and $1 \mathrm{C}$, respectively, with negligible capacity loss. Overall, the electrochemical performance of the $\mathrm{Li}_{2} \mathrm{FeSiO}_{4} / \mathrm{C}$ cathode material is superior to that of the pristine $\mathrm{Li}_{2} \mathrm{FeSiO}_{4}$, in terms of electrochemical stability and reversible capacity. This suggests that electrochemical properties of $\mathrm{Li}_{2} \mathrm{FeSiO}_{4}$ can be significantly improved by coating a carbon layer. The conductive carbon layer may not only suppress the particle growth of $\mathrm{Li}_{2} \mathrm{FeSiO}_{4}$ during calcinations, but also improve the conductivity of the $\mathrm{Li}_{2} \mathrm{FeSiO}_{4}$ cathode material.

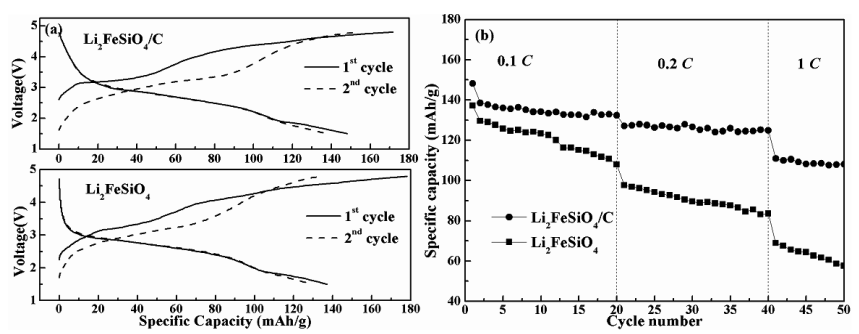

Fig. 4. (a) Charge-discharge profiles and (b) cyclic performances of $\mathrm{Li}_{2} \mathrm{FeSiO}_{4}$ and $\mathrm{Li}_{2} \mathrm{FeSiO}_{4} / \mathrm{C}$.

In order to understand the improved electrochemical performance of the $\mathrm{Li}_{2} \mathrm{FeSiO}_{4} / \mathrm{C}, \mathrm{AC}$ impedance measurement was carried out for both pristine and $\mathrm{Li}_{2} \mathrm{FeSiO}_{4} / \mathrm{C}$ electrodes at a $50 \%$ state of charge (SOC). As shown in Fig. 5, the impedance spectra exhibit a depressed semicircle in the high-frequency range and a sloping line with almost the same gradient in the low-frequency range. The intercept at $Z^{\prime}$ axis in high frequency corresponds to the ohmic resistance $\left(R_{\Omega}\right)$. The semicircles are attributed to the charge transfer resistance, while the sloping lines are correspondent to the typical Warburg behavior. Based on this understanding, an equivalent circuit model is given in the inset in Fig. 5 . In the equivalent circuit model, $R_{\Omega}$ refers to the ohmic resistance between the working electrode and the reference electrode, $R_{\mathrm{ct}}$ represents the charge transfer resistance, which can be determined by the value of the semicircle on the $Z^{\prime}$ axis, and $C P E_{\text {ct }}$ is the constant phase-angle element depicting the non-ideal capacitance of the double layer. $R_{\mathrm{s}}$ refers to the resistance for the lithium ion diffusion in the surface layer, $C P E_{\mathrm{w}}$ is the constant phase-angle element describing the non-ideal capacitance of the surface layer, and $Z_{\mathrm{W}}$ is the Warburg impedance [11].

In this work, $R_{\Omega}$ values are much smaller and negligible for both cathode materials when compared with the

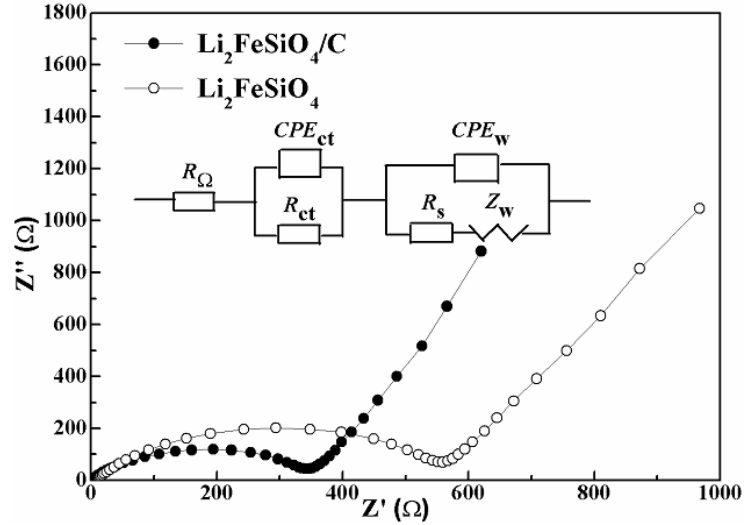

Fig. 5. EIS plots of $\mathrm{Li}_{2} \mathrm{FeSiO}_{4}$ and $\mathrm{Li}_{2} \mathrm{FeSiO}_{4} / \mathrm{C}$ acquired at $50 \% \mathrm{SOC}$ with the equivalent circuit as an inset.

charge transfer resistance, where $R_{\text {ct }}$ values are $350 \Omega$ and $560 \Omega$ for the $\mathrm{Li}_{2} \mathrm{FeSiO}_{4} / \mathrm{C}$ and pristine $\mathrm{Li}_{2} \mathrm{FeSiO}_{4}$ electrode, respectively. Therefore, carbon layer decreases the charge transfer resistance in the $\mathrm{Li}_{2} \mathrm{FeSiO}_{4} / \mathrm{C}$ cell, indicating an enhancement in the kinetics of lithium-ion diffusion and charge transfer reaction.

\section{Conclusions}

$\mathrm{Li}_{2} \mathrm{FeSiO}_{4} / \mathrm{C}$ cathode materials exhibit an improved rate capability and cycling performance compared with the pristine $\mathrm{Li}_{2} \mathrm{FeSiO}_{4}$. TEM analysis demonstrated that the coating of a nanolayer carbon $(1.5-3 \mathrm{~nm}$ in thickness) on the $\mathrm{Li}_{2} \mathrm{FeSiO}_{4} / \mathrm{C}$ cathode material has been realized by the carbonization of glycolic acid during calcination. EIS analysis indicates that the improvement of the electrochemical properties of $\mathrm{Li}_{2} \mathrm{FeSiO}_{4} / \mathrm{C}$ can be ascribed to the decrease in the charge transfer resistance. $\mathrm{Li}_{2} \mathrm{FeSiO}_{4} / \mathrm{C}$ could be used as a potential cathode material for lithium ion batteries.

\section{Acknowledgments}

This work is financially supported by the Australian Research Council through an ARC Linkage project (LP0989134).

\section{References}

[1] M. Armand, J.M. Tarascon, Nature 451, 652 (2008)

[2] A.K. Padhi, K.S. Nanjundaswamy, J.B. Goodenough, J. Electrochem. Soc. 144, 1188 (1997)

[3] M.S. Islam, R. Dominko, C. Masquelier, C. Sirisopanaporn, A.R. Armstrong, P.G. Bruce, J. Mater. Chem. 21, 9811 (2011)

[4] M. de Dompablo, J.M. Gallardo-Amores, J. Garcia-Martinez, E. Moran, J.M. Tarascon, M. Armand, Solid State Ionics 179, 1758 (2008)

[5] W. Xing-Long, J. Ling-Yan, C. Fei-Fei, G. Yu-Guo, W. Li-Jun, Adv. Mater. 21, 2710 (2009) 
[6] H. Joachin, T.D. Kaun, K. Zaghib, J. Prakash, J. Electrochem. Soc. 156, A401 (2009)

[7] W. Yonggang, W. Yarong, H. Eiji, W. Kaixue, Z. Haoshen, Angew. Chem. Int. Ed. 47, 7461 (2008).

[8] Y. Wang, B. Sun, J. Park, W.S. Kim, H.S. Kim, G.X. Wang, J. Alloys Comp. 509, 1040 (2011)

[9] Z.L. Gong, Y.X. Li, Y. Yang, Electrochem. Solid-State Lett. 9, A542 (2006)

[10] K. Zaghib, A.A. Salah, N. Ravet, A. Mauger, F. Gendron, C.M. Julien, J. Power Sources 160, 1381 (2006)

[11] L.M. Li, H.J. Guo, X.H. Li, Z.X. Wang, W.J. Peng, K.X. Xiang, X. Cao, J. Power Sources 189, 45 (2009)

[12] S. Zhang, C. Deng, S.Y. Yang, Electrochem. Solid-State Lett. 12, A136 (2009).
[13] Z.L. Gong, Y.X. Li, G.N. He, J. Li, Y. Yang, Electrochem. Solid-State Lett. 11, A60 (2008).

[14] R. Dominko, M. Bele, M. Gaberscek, A. Meden, M. Remskar, J. Jamnik, Electrochem. Commun. 8, 217 (2006)

[15] R. Dominko, J. Power Sources 184, 462 (2008)

[16] T. Muraliganth, K.R. Stroukoff, A. Manthiram, Chem. Mater. 22, 5754 (2010).

[17] A. Nyten, A. Abouimrane, M. Armand, T. Gustafsson, J.O. Thomas, Electrochem. Commun. 7, 156 (2005).

[18] A. Nyten, S. Kamali, L. Haggstrom, T. Gustafsson, J.O. Thomas, J. Mater. Chem. 16, 2266 (2006) 